DOI: $10.22363 / 2312-9182-2019-23-2-523-543$

\title{
Gender-Neutral Linguistic Transformations of Messianic Scriptures in the Modern Anglican Homiletic Literature
}

\author{
Konstantin S. Sharov \\ Moscow State University \\ 27 bld, 4 Lomonosovsky ave., Moscow, GSP-1, 119991, Russia
}

\begin{abstract}
Actuality. Our time is characterised by the penetration of egalitarian ideas of Western liberalism and political correctness in the sphere of language. Language, speech, communication practices are reviewed and revised to determine if they are politically correct. Religious and sacred texts of Christianity and Judaism do not stand aside from the careful examination of the followers of the ideas of compiling a politically correct Bible. The purpose of this article is to find out if it is possible to change the texts of English translations of the Christian Bible, from a theological and linguistic point of view, and if it is possible to consider gender-neutral versions of Messianic passages of the English Bible as authentic, suitable for the correct transmission of meaning, i.e. reading, theological and historical analysis, as well as liturgical practice. The object of the research is represented by the texts of several widely used in modern Anglicanism gender-neutral English versions of the Bible: The Inclusive Bible: The First Egalitarian Translation by Priests for Equality (IBFET, 2009); New English Translation (NET, 1998); New International Version Inclusive Language Edition (NIVI, 1995). King James' Bible original version (KJV) of 1611 edition is used as a reference point. Research techniques include the method of contextual analysis, comparative method, structural method, comparative historical method. Such taxonomic units of sacred Messianic texts as son of God, son of man, the lord, the master, the king, heaven kingdom, constructions of common grammatical gender are analysed. It is demonstrated that in almost all cases of gender-neutral constructions use, the meaning of the text changes: from insignificant changes to the reproduction of openly heretical views from the viewpoint of traditional Anglicanism. Our study shews that gender-neutral language introduces new feminist meanings into Messianic sacred texts, which were not previously contained there. Genderneutral English translations of the Christian Bible cease to be canonical from the point of view of Christian theology. Nevertheless, gender-neutral philological strategies of modifying the ways of modern Anglican preaching can be an extremely interesting and instructive example of the fact that in the modern world certain social and political discourses can stand behind Christian homiletics.
\end{abstract}

Keywords: Gender-neutral translation, gender-neutral language, English Bible, modern Anglican preaching, political correctness, Messianic sacred texts

\section{For citation:}

Sharov, Konstantin (2019). Gender-Neutral Linguistic Transformations of Messianic Scriptures in the Modern Anglican Homiletic Literature. Russian Journal of Linguistics, 23 (2), 523-543. doi: 10.22363/2312-9182-2019-23-2-523-543. 


\title{
Гендерно-нейтральные лингвистические трансформации мессианских священных текстов в современной англиканской гомилетической литературе
}

\author{
К.С. Шаров \\ Московский Государственный Университет имени М.В. Ломоносова \\ Ломоносовский проспект, 27, к. 4, ГСП-1, Москва, 119991, Россия
}

\begin{abstract}
Аннотация
Наше время характеризуется проникновением эгалитаристских идей западного либерализма и политической корректности в сферу языка. Язык, речь, коммуникативные практики подвергаются пересмотру и ревизии на предмет, корректны ли они политически. Религиозные и священные тексты христианства и иудаизма не остались в стороне от тщательного рассмотрения последователями идей составления политкорректной христианской проповеди, которая должна быть основана на новых политкорректных переводах Библии. Цель данной статьи - выявить группы стратегий изменения текстов английских переводов христианской Библии, использующихся в современности для гомилетических целей в Церкви Англии и Епископальной церкви. Объектом исследования являются тексты нескольких широко распространенных в современном англиканизме гендерно-нейтральных английских версий Библии: The Inclusive Bible: The First Egalitarian Translation by Priests for Equality (IBFET, 2009); New English Translation (NET, 1998); New International Version Inclusive Language Edition (NIVI, 1995). В качестве точки отсчета используется английская Библия короля Иакова 1611 г. издания. Методика исследования включает метод контекстного анализа, сопоставительный метод, структурный метод, сравнительно-исторический метод. Проанализированы такие таксономические единицы священных мессианских текстов, как son of God, son of man, the lord, the master, the king, heaven kingdom, конструкции общего грамматического рода. Установлено, что практически во всех случаях использования гендерно-нейтральных конструкций изменяется смысл текста: от несущественных изменений до воспроизводства еретических воззрений с позиций традиционного англиканства. Проведенное исследование показывает, что гендерно-нейтральный язык вносит новые феминистские смыслы в мессианские священные тексты, ранее там не содержавшиеся, а гендерно-нейтральные английские переводы христианской Библии перестают быть каноничными с точки зрения христианской теологии. Тем не менее, гендерно-нейтральные филологические стратегии видоизменения англиканской проповеди могут быть крайне интересным и поучительным примером того, что в современном мире за христианской гомилетикой могут стоять определенные социальные и политические дискурсы.
\end{abstract}

Ключевые слова: гендерно-нейтральный перевод, гендерно-нейтральный язык, английская Библия, современная англиканская проповедь, политическая корректность, мессианские священные текстьл

\section{Для цитирования:}

Шаров К.С. Гендерно-нейтральные лингвистические трансформации мессианских священных текстов в современной англиканской гомилетической литературе // Вестник Российского университета дружбы народов. Серия: Лингвистика = Russian Journal of Linguistics. 2019. T. 23. No 2. C. 523-543. doi: 10.22363/2312-9182-2019-23-2-523-543. 


\section{1. ВВЕДЕНИЕ}

С зарождением современного феминизма в 1960-е гг. его притязания коснулись изменения норм и правил английского языка для того, чтобы отразить в новых, исправленных формах толерантное и политкорректное отношение к женщинам и сексуальным меньшинствам (Гендер и язык 2005: 8).

Например, в рамках феминистской лингвистики предлагается переконструировать процессы словоупотребления таким образом, чтобы во всех случаях, когда нужно делать референцию на человека вообще, слова с амбивалентным смыслом были упразднены в устной и письменной речи. Так, предлагается вместо формы «тап» использовать слово «huтап». Все однокоренные слова должны быть заменены по требованию феминизма: например, «mankind» должен трансформироваться в «human beings», «man-made» — превратиться в «synthetic» или «manufactured》, «fireman» — B «firefighter », «businessman» — B «business executive», «policeman» — B «police officer», «cattle farm》 — B «animal prison», «congressman» — B «congress representative», «chairman» — B «chairperson» (Curzan 2003: 142).

Подобные лингвистические метаморфозы изобретены Американским национальным советом учителей английского языка в рамках программы развития политкорректности (Карасев 2017: 120; Шаров 2007: 51; Шаров 2010: 35-36; Шаров 2012: 41). Введение в речевой оборот таких неологизмов подчас становится инструментом реализации различных неолиберальных социополитических стратегий (Донских 2015: 32; Шаров 2006: 54; Шаров 2015: 211; Donskikh 2018: 415). Зачастую эти стратегии направлены на доминирование меньшинств (Карасев 1993; Карасев 1999; Шаров 2013; Sassin et al 2018).

Движение в поддержку политической корректности предлагает выбросить из языка все конструкции, которые реферируют к мужчине, но оставить все те, которые относятся к женщине, и особенно те, которые подчеркивают высокий социальный статус женщин и их положительные этические качества (Хитрук 2016: 103; Castelli 1990: 27). Идеологи этого движения настаивают на необходимости избавиться от мужского грамматического рода, не использовать личные и притяжательные местоимения мужского рода, там, где можно - не использовать референцию на пол вообще (например, отказаться от употребления акронимов $M r$. «мистер» и Mrs. «миссис»), а где нельзя - подчеркивать лидирующее положение женщин: вместо «man and wife» ${ }^{1}$ в церковных службах говорить «wife and husband $\gg^{2}$ (Deeb-Sossa, Kane 2007: 155).

Естественно, христианское Священное Писание, равно как и Талмуд, не могли не попасть в сферу пристального внимания идеологов политкорректного языка, ведь с их точки зрения, христианские и иудейские священные тексты отличаются крайним шовинизмом и репрезентируют древние патриархальные смыслы в сегодняшней реальности (Gomola 2010: 194 - 196). Как говорит известный феминистский теолог Элизабет Мольтманн-Вендель, священные тексты традиционно ложатся в основу антиженской патриархальной устной и литературной гомиле-

\footnotetext{
1 Муж и жена (англ.).

2 Жена и муж (англ.).
} 
тики, т.е. всей совокупности христианских проповедей, читаемых в церквях во время или после богослужений, а также распространяемых в среде прихожан в виде книг, видеозаписей, фильмов, CD- и DVD-дисков (Мольтманн-Вендель 1991: 95-96). Такая проповедь в современном мире помогает закреплять гендерное и прочее социальное неравенство: белые мужчины еще больше угнетают женщин, детей, животных, нетрадиционно ориентированных в сексуальном плане людей, цветных и темнокожих и лишать их законных прав (Barr 2014: 299). По словам Александра Назарчука, в современном сетевом информационном обществе религиозная проповедь не будет иметь серьезного отклика, если не будет направлена к конкретному человеку и его проблемам, т.е. не будет по-настоящему инклюзивной и толерантной (Назарчук 2008: 69-70; Назарчук 2009: 155). Григорий Киселев сходным образом отмечает, что вытеснение женских смыслов из религиозной проповеди на периферию было долгим историческим процессом, который, по его словам, привел к тому, что Бог и человек в Библии, которая закрепляла такую проповедь текстуально, стали сильно разобщенными (Киселев 2001: 10-11; Киселев 2011: 24).

О. Воронина из Института философии РАН придерживается взгляда, что патриархальная иудейская, а впоследствии и христианская проповедь, репрезентируя социальное неравенство древнего Израиля, легитимировала понятие о Боге как об Отце, в то время как во многих соседних с Израилем народах древности было понимание Бога как некой Матери на Небесах (Воронина 2007: 60-61). Об этом также упоминает О. Райкова (Райкова 2016: 74).

Немецкая исследовательница феминизма, филолог Эмили Шюсслер-Фьоренца пишет следующее:

Все библейские тексты написаны в грамматически маскулинном ключе, на языке, встроенном в патриархальную культуру, религию и общество, и который канонизировался, переводился и интерпретировался многими поколениями мужчин. Без сомнения, Библия - это ориентированная на мужчин книга! (SchüsslerFiorenza 1992: 53).

Далее Шюсслер-Фьоренца утверждает, что традиционная (патриархальная) и феминистская гомилетика, основанные на мужском и женском прочтении Библии, приводят к совершенно различному результату. Мужчина при чтении духовной литературы или во время христианской проповеди раскрепощен, он чувствует себя вполне комфортно за счет того, что рисует у себя в воображении патриархальную культуру Иудеи и израильского народа. Женщина же все время напряжена и вынуждена относиться к каждой строчке гомилетических текстов или каждому слову проповедника с «герменевтикой подозрения», поскольку только такое подозрение может спасти ее от включения в дискурс мужского желания и подавления (Schüssler-Fiorenza 1995: 36).

Отечественный филолог Н. Габриэлян отмечает:

В языке... использование только мужского рода при построении синтагм просматривается на уровне причастий, глаголов прошедшего времени, числительных, множественного числа существительных и т. д. Эта тенденция «выталкивает» женщину из многих грамматических форм, тем самым тщательно дозируя ее присут- 
ствие в языковом пространстве... оказывает на психику более устойчивое воздействие, нежели грубые виды дискриминации, и проникает в более глубокие пласты именно в силу своей неочевидности (Габриэлян 1993: 174).

Хотя данная исследовательница говорит о русском языке, логика феминизма при изменениях текста английской Библии полностью соответствует данному программному заявлению.

В рамках феминистского дискурса в наши дни появляются все новые политкорректные и эгалитаристские английские переводы Библии, которые пытаются использовать термины гендерно-нейтрального языка для адекватной передачи социальных смыслов в англиканской гомилетической (проповеднической) литературе (Bible Gateway n.d.). При этом Библия короля Иакова 1611 г., которая на протяжении почти трех веков являлась авторизованной, единственно правильной и всеобщей для англиканского сообщества версией Библии (Библейские переводы 1891: т. 3А, 681), отвергается как транслирующая смыслы патриархального господства и тем самым неприемлемая для современного либерального общества западного образца (Collins n.d.; Dallas 2007; Gross 2008: 80-81).

В данной статье проводится исследование стратегий внедрения гендернонейтральных оборотов и конструкций в текст мессианских отрывков христианской Библии с целью последующего использования современными англиканскими пасторами и церковными писателями в литературной гомилетике. Под мессианскими текстами обычно понимаются фрагменты Библии, прямо или косвенно повествующие о Мессии, Иисусе Христе. Так, мессианскими текстами будут, например, Новый Завет, ветхозаветные пророчества о Христе, часть закона Моисея, в которой предсказано будущее пришествие Мессии на Землю. Конечной целью моей работы является выяснить лингвистические стратегии гендернонейтральной трансформации современной англиканской гомилетики как литературного жанра.

Для анализа используются английские версии Библии, поскольку к настоящему времени они оказались в наибольшей степени затронуты тенденциями гендерно-нейтральных изменений. В начале XXI в. подобные попытки переделать язык Библии приобрели лавинообразный характер (Jacobs 2001: 82). Несмотря на то, что среди многих представителей англиканского духовенства до сих пор сохраняется осторожная позиция по отношению к подобным изменениям (Grudem, Osborne 1997; Grudem 1998; Poythress, Grudem 2000), политкорректных переводов с каждым годом становится все больше, и все больше верующих в англиканском мире начинает катехизироваться с помощью таких политкорректных Библий, которых к настоящему времени выпущено уже более сорока (What does the Bible say... n.d.).

Попробуем разобраться, на что в англиканской проповеди и священных текстах направлена феминистская и политкорректная критика.

В целом, стратегии перестройки англиканской литературной гомилетики (для сравнения будем использовать в качестве эталона английскую Библию короля Иакова 1611 г.) можно условно разделить на несколько групп, вклю- 
чающих различающиеся по силе воздействия на священный текст приемы и методы (Minton 2003: 141):

А) изменения грамматических форм текста для достижения его нового герменевтического прочтения, как это сейчас обычно делается вне богословия, т.е. в политическом, академическом и ином дискурсе в западных странах, например, использование общего грамматического рода, использование местоимения she или they вместо he в неопределенно-родовых случаях;

В) устранение или затушевывание маскулинных форм в контексте богословия и истории церкви, искусственное введение феминности, например, использование «братья и сестры» вместо «братья»;

С) изменение богословского смысла, переданного на языке оригинала, с помощью использования гендерно-инклюзивных вариантов современного английского языка, что приводит к подмене понятий, например, использование форм «child of God» («ребенок Бога») или «human being / human one / the mortal» («человеческое существо / некий человек / смертный») вместо «son of God» («сын Божий») и, соответственно, «son of man» («сын человеческий»).

D) феминистское переосмысление центральных теологических понятий, например, название Бога не Отцом Небесным, а «Отцом и Матерью на небесах».

\section{2. ЛИНГВИСТИЧЕСКИЕ ПРИЕМЫ СТОРОННИКОВ ГЕНДЕРНО-НЕЙТРАЛЬНОГО ЯЗЫКА}

Остановимся более подробно на различных лингвистических приемах сторонников гендерно-нейтрального языка в англиканской проповеди, связанных с переосмыслением мессианских текстов Писания, т. е. текстов, говорящих об Иисусе Христе.

\subsection{The Son of God}

В таких строфах Нового Завета, как Мф. 3:17, Ин. 1:14, Ин. 3:16-17, Гал. 4:4-7 напрямую говорится о том, что Иисус Христос - Сын Божий. Но ряд англиканских церковных писателей, работающих в парадигме политкорректности, стремясь выбросить из своих произведений упоминание названий любых мужских степеней родства, таких как «сын», «брат», «отец», заменяют слово son (сын) в данных контекстах на слово child («ребенок»), так что вместо выражения «Сын Божий» получается «ребенок Божий» (Fuchs 2008: 47). Последнее выражение также часто используется в Библии, однако в совершенно других смыслах и никогда не относится ко Христу. Изменение словосочетания son of God на child of God приводит к лингвосемантической путанице, поскольку мы уже не можем различить случаи различного словоупотребления в текстах Писания.

Феминистские переводчики указывают, что их переводы могут быть гораздо ближе оригиналу, чем традиционалистские английские переводы Библии, такие как, например, Библия короля Иакова 1611 г., Библия Уиклиффа или Библия ДуэРеймс (Fuchs 2008: 48) Проанализируем это утверждение подробнее.

В греческих текстах Нового Завета используется слово vió

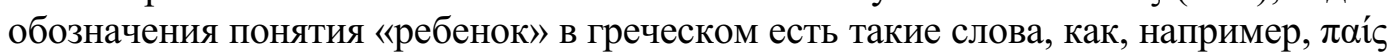
или $\tau \varepsilon ́ \kappa v o v$, которые по отношению к Иисусу не используются, хотя употребляются 
в других контекстах (Biblical Revelation and Inclusive Language 1998). Далее, английское слово child описывает ребенка безотносительно к полу, чего, собственно, и хотят достичь авторы политкорректных Библий, вводя в новозаветное повествование такие изменения (Robbins 2001: 410). Но какой смысл менять язык, устраняя мужскую степень родства, если мы знаем, что Иисус Христос воплотился в Своем человеческом естестве как мужчина? И третье соображение, которое не позволяет признать правоту замены son на child, кроется в том, что как в римском обществе I в., так и еврейском обществе Иудеи, только сын (неважно, родной или приемный) мог юридически действовать как уполномоченное лицо главы семейства и обладал всей полнотой доверенности, о чем пишет ряд отечественных и зарубежных исследователей древнего и античного права (Шевцов 2010: 19, 21; Кофанов 2010: 68; Пиков 2010: 116; Санников 2010: 83-84; Baranov 2018: 435, 437; Collins n.d.; Protopopova, Garadja 2018: 427; ср. Гал. 4:1—7). Поэтому, говоря о Христе как о Сыне Божьем, мы подразумеваем не только его сыновнее родство по отношению к Богу Отцу, но и всю полноту божественной власти, которой Христос обладает. При использовании слова child это остается совершенно непонятным.

\subsection{The Son of Man}

Вместо словосочетания son of man (сын человеческий) в политически корректной англиканской гомилетической литературе, основанной на политически корректных переводах Библии, авторы подставляют парафразы human being, human one или the mortal (человеческое существо, некий человек / некто, смертный) (Stein 2008: 112).

Сын Человеческий - термин, пришедший из Ветхого Завета, на древнееврей-

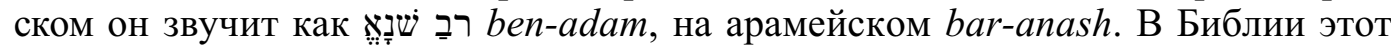
термин используется в трех смыслах и может означать:

1) просто человека, к которому обращался Бог (Чис. 23:19, Пс. 8:4, Иез. 2:1, Дан. 8:17; Екк. 3:18);

2) ангела (Откр. 14:14);

3) Мессию (Дан. 7:13).

Много раз в древнееврейских пророчествах и ветхозаветных текстах мы встречаем это наименование Христа (Calvo 2018: 368). Иногда оно могло обозначать ангела, но видом все равно подобного Христу (как, например, в повествовании о трех отроках, брошенных в вавилонскую печь царя Навуходоносора см. Дан. 3:21-100). Христос постоянно называл Себя Сыном Человеческим и очень редко - Сыном Божьим, и иудеи прекрасно понимали, что Он, именуя Себя так, свидетельствует, что Он есть ожидаемый всеми Мессия; это становится ясно хотя бы из контекста строфы Ин. 12:34:

The people answered him, We haue heard out of the Law, that Christ abideth for euer: and how sayest thou, The Sonne of man must bee lift vp? Who is this Sonne of man? (Народ отвечал Ему: мы слышали из закона, что Христос пребывает вовек; как же Ты говоришь, что должно вознесену быть Сыну Человеческому? кто Этот Сын Человеческий?).

Здесь характерно то, что иудеи, задавая Христу вопрос «кто такой Сын Человеческий?», задают его не в смысле своего незнания, а в смысле агрессивного 
противления своих собственных несовершенных знаний тому совершенному знанию, которое давал Иисус. Иудеи явно знали из закона и пророков, кто такой Сын Человеческий - это было название чаемого всеми Мессии. С особенным пиететом к наименованию «Сын Человеческий» относились ессеи, которые считали его чуть ли не равным имени Бога (Tantlevskij 2016). Однако считая, что Христос должен прийти на Землю как царь и воссесть на вечном престоле в Иерусалиме, они не могли понять, что Сын Человеческий должен вознестись на Небеса отсюда и семантическое несоответствие слов Спасителя и их знания (Biblical Revelation and Inclusive Language 1998: 29; Terezis, Petridou 2017).

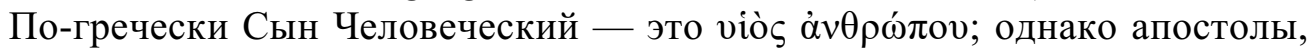
проповедуя в грекоговорящих странах, предпочитали называть Иисуса Сыном Божьим, поскольку эллины, чуждые иудейской культуре и древнего понятия о Сыне Человеческом, чаще всего воспринимали этот термин именно в первом смысле - как отсылку просто к обыкновенному человеку и, будучи далекими от древнееврейских пророчеств, верований и преданий, не понимали, что выражение «Сын Человеческий» свидетельствует о Сыне Божьем (Tantlevskij 2017; Tantlevskij 2019; Welch 1992: 53). Отсюда радикальное несоответствие количества

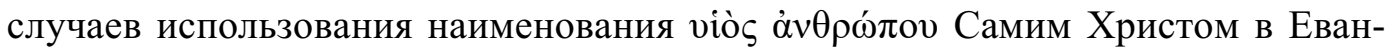
гелиях (около 70) и апостолами в Деяниях и Посланиях (считанные единицы) (Stein 1995: 177).

Если мы заменим наименование «Сын Человеческий» в английской Библии на гендерно-нейтральное «смертный», мы потеряем отсылку ко Христу и оставим только первый смысл, т. е. сделаем ту же ошибку, что и грекоговорящее население Римской империи I в., слушавшее проповедь апостолов. Мы тогда невольно отсеем многовековую ветхозаветную религиозную, филологическую и культурную традицию, связанную со вполне определенным пониманием термина «Сын Человеческий».

В качестве примера возьмем историю убиения первомученика Стефана. В Библии короля Иакова читаем, что Стефан сказал иудеям:

And said, Behold, I see the heauens opened, and the Sonne of man standing on the right hand of God (и сказал: вот, я вижу небеса отверстые и Сына Человеческого, стоящего одесную Бога) (Деян. 7:56).

Политкорректная английская Библия The Inclusive Bible: The First Egalitarian Translation (by Priests for Equality) (2009) изменяет отрывок так:

"Look!" he exclaimed. "I see the heavens opened, and the Chosen One standing at God's right hand!" (Посмотрите! — он воскликнул. — Я вижу небеса открытыми и Некого Избранного, стоящего одесную Бога) (The Inclusive Bible 2009: 721).

Семантически это вовсе не то же самое, что в оригинале, и что хотел сказать первомученик Стефан. Подобное серьезное лингвосемантическое искажение происходит и в стихе Ин. 3:13-14, когда мы читаем о ночном разговоре Иисуса с Никодимом, и в Лк. 22:48, когда описывается, как Иуда предает Христа, и практически во всех иных местах, где Христос говорит о Себе как о Сыне Человеческом. Иуда не мог предать некоторого безличностного и собирательного human 
being или human one (одного из людей, некого человека). Иисус говорит Иуде в Гефсиманском саду: «But Iesus said vnto him, Iudas, betrayest thou the sonne of man with a kisse?» (Иисус же сказал ему: Иуда, целованием предаешь ли ты Сына Человеческого?) (Лк. 22:48). Разумеется, Христос не имел в виду, что Иуда предает просто некого представителя рода человеческого.

Также в гендерно-нейтральных английских переводах Нового Завета в отношении к Иисусу Христу используются фразы Only Begotten, God's Own, Eternally Begotten и Promised One (Единоутробный, Свой Богу, Превечно Рожденный, Обещанный) (Kettemann, Marko 2005: 211; The Queen James Bible 2012: 5). Ни одна из них не несет того же смысла, что и Son of man и не может рассматриваться как полностью лингвистически эквивалентная замена. Например, в имени God's Own звучит принижение достоинства Христа, поскольку фраза уоu are my own выражает ласковое обращение, эмоции, любовные чувства и на русский ближе всего может быть переведена ты моя зайка, ты мое солнще. Говоря ту оwn one, мы имеем в виду my darling. Называть так Христа мы можем, например, в акафистах и славословиях, но апостолы так Его называть, безусловно, не могли.

Самый известный ветхозаветный пассаж о грядущем Сыне Человеческом из пророчества Даниила

I saw in the night visions, and behold, one like the sonne of man, came with the clouds of heauen, and came to the Ancient of daies, and they brought him neere before him (Видел я в ночных видениях, вот, с облаками небесными шел как бы Сын человеческий, дошел до Ветхого днями и подведен был к Нему) (Дан. 7:13)

в гендерно-нейтральной Библии превращается в совершенно другой текст:

I gazed into the visions of the night once again, and I saw, coming on the clouds of heaven, one who looked human, but somehow more than human. This One came to the Ancient One and was led into the Divine Presence (Еще раз я всматривался в ночные видения, и я увидел на облаках небесных некого, кто выглядел как человек, но каким-то образом был больше чем человек. Этот Некто подошел к Некому Древнему, и был введен в Божественное Присутствие) (The Inclusive Bible 2009: 495).

Помимо того, что этот текст стилистически корявый, он не передает исходного древнееврейского смысла. Такой вывод легко подтверждается сличением цитаты с арамейским оригиналом:

Видел я в ночных видениях, вот, с облаками небесными шел как бы Сын человеческий, дошел до Ветхого днями и подведен был к Нему) (Дан. 7:13)

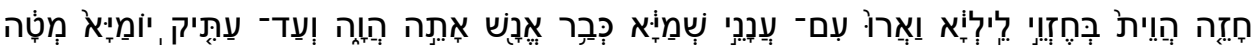

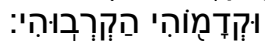

где

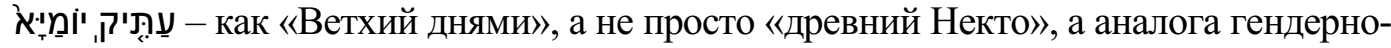
нейтральному термину «божественное присутствие» в исходной фразе на арамейском вообще нет.

Наконец, в некоторых случаях, когда современные англиканские политкорректные проповедники не делают никакой уместной с их точки зрения замены словосочетания son of man, они склонны попросту его выбросить из контекста и вписать в этот контекст сконструированные ими самими строки/слова. Разумеется, тогда получается семантически искаженное повествование, не передающее 
истинной картины новозаветных событий (Carson 1998: 71; De Waard, Nida 1986: 25). Вспомним, как после побоев и издевательств над Иисусом римские воины одели Его в багряницу и возложили терновый венок на голову, желая поглумиться над Ним, но, по сути, тем самым подчеркнув Его царственность (Ин. 19:1-4). После этого Пилат, пораженный стойкостью и мужеством Христа, которые он не думал

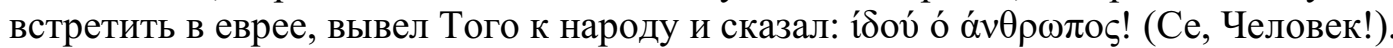
У короля Иакова это Behold the man! (Узрите Человека!) (Ин. 19:5). Пилат, говоря эти слова, хотел подчеркнуть, что Христос есть совершенный Человек, Сын Божий и Царь - все это коннотируется одним словом man. В политкорректных Библиях это место просто вычеркнуто из Евангелия. Там Пилат говорит народу: «Look upon the one you accuse!» (посмотрите на того, кого вы обвиняете!). Это совсем не одно и то же.

\subsection{The Lord}

Иисус часто называется Господом Своими учениками, иудеями и Сам говорит о Себе, что Он - Учитель и Господь: Ye call me Master and Lord, and ye say well: for so I am (Вы называете Меня Учителем и Господом, и правильно говорите, ибо Я точно то) (Ин. 13:13).

Слово lord - это господин, английский лорд, землевладелец, властитель, наконец, Господь. Политкорректные англиканские проповедники считают, что «для того, чтобы устранить сексистские и классовые коннотации этого слова, нужно использовать названия Иисуса „Суверен“, „Спаситель“ и „Иисус царствует“» (The New Testament and Psalms 1995: 2). Думаю, любой английский школьник сможет показать разницу между словами lord и sovereign. Суверен — монарх, которому мы подчиняемся вынужденно, поскольку мы - его подданные, и мы не можем не подчиняться, ибо в таком случае мы будем обвинены в измене короне со всеми вытекающими последствиями. Лорд - наш господин, которому мы подчиняемся добровольно и против которого можем восстать, если он будет несправедлив, против которого можем подать в суд. Нина Габриэлян, критикуя слово лорд (господин), говорит следующее:

Вряд ли слово «господа» (единственное число - «господин», т.е. хозяин, владелец) можно считать всего лишь нейтрально окрашенной частью лингвистической оппозиции, только указанием на половую принадлежность. «Господин» - это указание не только на пол, но и на роль, значимость этого пола, его доминирующую функцию. В этом раскладе и «дамы» - знак не только пола, но и иерархической подчиненности. Таким образом, обращение «дамы и господа» — это иерархическая структура, замаскированная под лингвистическую оппозицию (Габриэлян 1993: 171).

Недовольство феминистской мыслительницы словом «господин» понятно: мы по своей собственной воле отдаем нашему господину часть своих свобод, чтобы приобрести какую-либо пользу или выгоду для себя. В христианском богословском смысле, как утверждает ряд отцов церкви, говоря Иисусу «Lord», верующие христиане приобретают Царство Небесное за счет отказа от свободы творить беззаконие и свободы пойти в вечную погибель, а гендерно-нейтральный перевод такой смысл устраняет. Но, например, из истории древнеримского общества мы знаем, что женщины наравне с мужчинами могли пользоваться титулами «госпожа», 
«патронесса», «мать города», «мать отечества», «мать армий», при этом данные титулы указывали на ее высокий социальный статус, зачастую более высокий, чем у всех мужчин, которые ее окружали (Шаров 2019: 108, 113). Поэтому проводить столь однозначные параллели между словом «господин» и понятием патриархального владыки, как это делает Габриэлян, я бы не стал.

\subsection{The Master}

Сходным образом в политкорректных английских Библиях подменяется слово «учитель». Дело в том, что в русском языке мы не вполне понимаем, в чем тут суть. В английском языке, в отличие от русского или старославянского, где понятие «учитель» обозначается одним словом, могут использоваться разные слова с различающимся смыслом. Так, переводиться как «учитель» будут слова teacher, mentor, tutor, master, school-master, preceptor, supervisor, professor - все они обозначают учителя, но с разными оттенками (Archibald-Barber n.d.). В Библии короля Иакова чаще всего используется слово the master. В феминистском дискурсе вместо него подставлено the teacher.

Ho the teacher - это просто некий школьный учитель, чужой нам человек, к которому мы приходим на занятия, приобретаем некие знания и после уходим домой, совершенно не интересуясь дальнейшей его судьбой. С другой стороны, the master - это учитель-мастер, понятие, восходящее к средневековым гильдиям и мастерству, преподававшемуся в них, а также - к понятию battle master (боевой мастер, учитель искусству ведения боя) (Федоров и др. 2015: 88). Это совершенно другой человек, чем the teacher. Ученики the master - не просто ученики, это своего рода подмастерья, обучающиеся всей премудрости и всему искусству, которыми владеет их учитель. Учитель постепенно передает им свои бесценные знания, которые нигде не записаны, и этим знаниям невозможно научиться с помощью учебников, а подмастерья овладевают неявным знанием. С другой стороны, есть и еще отличие the teacher и the master: первый зачастую не становится своим для ученика, и всегда сохраняется отчужденность, в то время как последний часто заменял ученикам отца; они жили, ели и пили вместе со своим учителем. Он был для них и воспитателем, и учителем, и хозяином, и приемным «отцом». Если у подмастерья умирал родной отец, учитель часто усыновлял его. Но даже если родной отец был жив, то во многих случаях он передавал свои права и полномочия по воспитанию мастеру, к которому отдавал сына в ученики - неважно, изготавливал ли этот мастер арфы или обучал сына на воина. Он мог дать ученику тычка или выпороть того розгами, но и одновременно предоставлял ему кров, питание, деньги и бесценные знания - по сути, делал из человека достойного члена общества (Бернатоните 2017: 131).

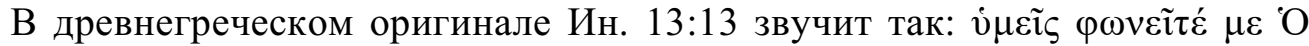

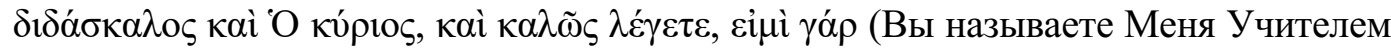
и Господом, и правильно говорите, ибо Я точно то). Здесь мы видим, что используется слово ки́рios, которое в греческом означает мастер, учитель, хозяин, владыка, которое в версии короля Иакова передается словом the master: Ye call me Master and Lord, and ye say well: for so I am. 
Перевод the teacher, предлагаемый в рамках политкорректной англиканской проповеди, убирает все эти оттенки, лишь оставляя смысл преподавания. Политкорректная критика в этом случае опять-таки вполне понятна, она направлена на устранение патриархального понятия «хозяин» (Ward 1994: 320), но как и прежде, она разрушает исходные библейские смысловые коннотации.

\subsection{The King}

Слово «король», «царь» рассматривается большинством либеральных переводчиков Библии как неполиткорректное (Meyers 2014: 10). Логика здесь достаточно проста.

Считается, что раз в современности, в эпоху расцвета политической корректности, большинство западных стран - это демократические республиканские режимы по форме правления, значит, сама политическая корректность напрямую связана с демократией (Andina 2015: 19). Таким образом, отсюда выводится, что наличие демократической формы правления делает возможным развитие и укрепление идей эгалитаризма и равноправия, которые были бы невозможны при монархическом авторитарном строе. Именно по этой причине новые англиканские проповедники хотят выбросить из своей проповеди понятия монарха, монархии и подставить термины, в которых не содержится намека на монархический строй и авторитарную форму правления (Martin 1990: 47-48).

Вместо слова king (царь) предлагается делать подстановку God (Бог), а понятие heaven kingdom (Царство Небесное) переделывается на reign of heaven (правление Небес) (Lathrop, Ramshaw 1993: 3).

Признаться, я не вижу здесь большой логики и особого смысла. Как мы помним из обсуждения слова lord, авторы гендерно-нейтральных Библий и политкорректные англиканские церковные писатели не против использования слова sovereign (суверен, сюзерен), но ведь суверен - и есть монарх, и это понятие является семантически эквивалентным слову king. Понятие суверена включает в себя понятие царя. Например, суверенами будут король, царь, конунг, халиф, султан, император, вождь племени и т.д. Здесь налицо некоторая внутренняя противоречивость антипатриархального гомилетического дискурса: признавать легитимность понятия «суверен», но нелегитимность понятия «царь». Далее, когда мы говорим reign, мы имеем в виду правление как процесс, а когда - kingdom, то и процесс, и территорию, и власть (Afonasin 2014: 25-26). Поэтому замена kingdom на reign сразу вычеркивает множество содержащихся в слове «царство» смыслов. Из-за этого reign of heaven (правление Небес), конечно же, не является лингвистически правильной и эквивалентной заменой понятию heaven kingdom (Царство Небесное).

\section{3. ЗАМЕНА ГРАММАТИЧЕСКИХ КОНСТРУКЦИЙ ДЛЯ ПЕРЕДАЧИ ОБЩЕГО РОДА}

В таких отрывках из Библии, как Пс. 1:1—3, Мф. 10:39, Ин. 11:25, Ин. 14:23, греческий и древнееврейский текст передает общий грамматический род с помощью маскулинных конструкций man... he who... Эти конструкции мужского 
рода широко использовались как в старо- и среднеанглийском, так и в современном языке для передачи общего грамматического рода (Curzan 2003: 36-38; Jones 1988: 47; Whorf 1937: 6). В новой англиканской гомилетике эти места предлагается трансформировать с помощью множественного числа как those... they who... (Fletcher 2014: 31) Если для некоторых мест Библии такая перестановка, в целом, смысл не искажает, то в ряде мест искажает существенным образом. Приведу характерный пример.

Часто общий грамматический род, передаваемый описываемыми лингвистическими конструкциями, в древнееврейском или древнегреческом языках действительно реферирует на мужской пол / гендер, но не напрямую, а опосредованно. Окончание 33-го псалма (в англиканской традиции 34-го псалма) таково:

${ }^{17}$ The righteous crie, and the Lord heareth; and deliuereth them out of all their troubles. ${ }^{18}$ The Lord is nigh vnto them that are of a broken heart: and saueth such as be of a contrite spirit. ${ }^{19}$ Many are the afflictions of the righteous: but the Lord deliuereth him out of them all. ${ }^{20}$ He keepeth all his bones: not one of them is broken. ${ }^{21}$ Euill shall slay the wicked: and they that hate the righteous shalbe desolate. ${ }^{22}$ The Lord redeemeth the soule of his seruants: and none of them that trust in him, shalbe desolate $\left({ }^{17}\right.$ Воззваша праведнии, и Господь услыша их, и от всех скорбей их избави их. ${ }^{18}$ Близ Господь сокрушенных сердцем, и смиренныя духом спасет. ${ }^{19}$ Многи скорби праведным, и от всех их избавит я Господь. ${ }^{20}$ Хранит Господь вся кости их, ни едина от них сокрушится. ${ }^{21}$ Смерть грешников люта, и ненавидящии праведнаго прегрешат. ${ }^{22}$ Избавит Господь душы раб Своих, и не прегрешат вси, уповающии на Него).

Обращает на себя внимание, что в Библии короля Иакова из приведенных строф только в строфах 19 и 20 используется форма мужского грамматического рода для передачи общего рода, в то время как в прочих строфах используется множественное число. Ни в церковнославянском Елизаветинском переводе, ни в Синодальном русском переводе 1876 г. этого нет, мы видим, что в наших переводах везде в данном отрывке используется множественное число, что несколько затемняет истинный смысл пророческого подтекста отрывка, в то время как Библия короля Иакова передает древнееврейский смысл точно.

Однако обратимся к древнееврейскому оригиналу строф 19 и 20 из 33-го псалма (у евреев этот псалом также идет под номером 34):

${ }^{19}$ Многи скорби праведным, и от всех их избавит я Господь (Пс. 33: 19 - нумерация строфы по Библии короля Иакова).

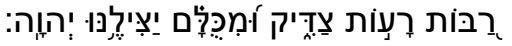

${ }^{20}$ Хранит Господь вся кости их, ни едина от них сокрушится.

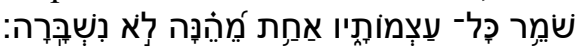

Здесь мы видим грамматические формы мужского рода ehtsem, а также существительное мужского рода единственного числа צִּ tsadic (праведник). Итак, английский перевод в Библии 1611 г. наиболее точным образом практически дословно передает все лингвистические нюансы древнееврейского оригинала, записанного царем Давидом. Теперь предположим, что мы перепи- 
сываем отрывок гендерно-нейтральным образом, как это сделано в Библии The Inclusive Bible (2009):

${ }^{17}$ But the just cry out, and Yhwh hears, and saves them from all their troubles. ${ }^{18} Y h w h$ is close to the brokenhearted and rescues those whose spirits are crushed. ${ }^{19}$ Many are the afflictions of the just; but Yhwh delivers them from all their troubles. ${ }^{20} Y h w h$ protects their very bones, and not one of them will be broken. ${ }^{21}$ Calamity will strike down these vicious curs, and the haters of justice will be condemned. ${ }^{22} Y$ hw ransoms the lives of the faithful, and none who take refuge in God will see punishment (The Inclusive Bible 2009: 382).

Оставляя в стороне соображения, что тетраграмматон $Y h w h$ (ЙХВХ), побуквенная передача буквами латиницы еврейского слова-тетраграммы !ה!n вместо the Lord (Господь) смотрится в английском, мягко говоря, несообразно здравому смыслу, обратим внимание, что в строфах 19 и 20, так же как и в других, англиканскими сторонниками гендеризации Библии подставлено множественное число. Но если в строфах 17-18, 21-22 это множественное число было у царя Давида, автора псалмов, сильно контрастируя с мужским родом единственного числа в стихах 19-20, то в гендерно-нейтральном английском переводе все звучит одинаково.

Так, оказывается, что Yhwh delivers them from all their troubles и Yhwh protects their very bones, and not one of them will be broken (ЙХВХ избавляет их от всех их бед и ЙХВХ защищает их собственные кости, и ни одна из них не сокрушится). Почему в этих стихах так важно передать мужской грамматический род (то, что, к сожалению, также отсутствует в русских переводах)? Потому что эти стихи пророческие: согласно словам апостола Иоанна Богослова (Ин. 19:36), For these things were done, that the Scripture should be fulfilled, A bone of him shall not be broken (Ибо сие произошло, да сбудется Писание: кость Его да не сокрушится). Апостол Иоанн подчеркивает, что использование в древнееврейском тексте строф 19 и 20 мужского грамматического рода единственного числа, а не множественного числа, как в других строфах, пророчески показывает за 11 веков до пришествия в мир Иисуса Христа, что когда Христос будет распят на кресте, римские солдаты не перебьют Ему голени, как это было обычно заведено при казни на крестах в римской провинции Иудея (Сазонова 2016: 58; Ringer n.d.; Strauss 1998а: 37).

Данный пример иллюстрирует, что, казалось бы, безобидная подстановка местоимений множественного числа they, them, themselves, their, которая широко практикуется в английском языке в рамках политкорректного дискурса за пределами сферы христианской гомилетики, при попытках нового гендерно-нейтрального перевода Библии может полностью изменить смысл божественного послания.

\section{4. ЗАКЛЮЧЕНИЕ}

Мы рассмотрели некоторые из наиболее показательных стратегий переписывания английских переводов Библии в рамках политически корректной сегодняшней англиканской проповеди. Суммируя, можно сказать, что их авторы, устраняя грамматический мужской род из текста своей проповеди, пытаются 
создать ощущение социального равноправия полов (Shakespeare 2009: 14). Однако на практике они часто достигают совсем иной цели - существенного лингвосемантического искажения священных христианских текстов. Политически корректные англиканские проповедники в современной церкви Англии и Епископальной церкви в угоду социальному дискурсу, стоящему за их проповедью, начинают отказываться от каноничности понимания Ветхого и Нового Завета, а также от базовых богословских концепций. Положительным моментом в такой гомилетике является то, что она нацелена на максимальную социальную инклюзивность и решение проблем всех социальных групп, в первую очередь - женщин. Однако выводы данных церковных писателей иногда начинают граничить с богословской ересью, а то и полностью транслировать еретические взгляды с позиций традиционного англиканства.

Авторы многих гендерно-нейтральных переводов Библии претендуют на то, что эти новые переводы доносят до читателя смысл намного ближе древним оригиналам, чем это делают традиционные переводы наподобие Библии короля Иакова 1611 г. (Fuchs 2008: 48; Whitehead, Perry 2015: 435) Однако наш анализ не показывает этого. Наоборот, внимательное сличение древнегреческих, древнееврейских и английских понятий убедительно демонстрирует, что традиционные английские переводы, ориентированные как на буквализм, так и на историкобогословскую передачу контекста, а также на литературную красоту и завершенность стиля, на поэтичность слога (староанглийская западносаксонская католическая версия X в., среднеанглийская католическая Библия Уиклиффа XIV в., новоанглийская Библия Дуэ-Реймс, новоанглийская англиканская версия короля Иакова), являются эталонами английского Священного Писания, которые вряд ли имеет смысл переделывать с лингвистической точки зрения. Почему так?

В традиционном богословии считается, что Бог и Его воля становятся известны из Его естественного откровения (телеологического провидения; наблюдения за разумным устройством природы; изучения законов природы и закономерностей в природе, размышлений о гармонии в мире; чудес в жизни людей) и специального откровения (исторических событий; слов пророкам; божественной воли, проявляемой в жизни общества и жизни отдельных его представителей или даже целых социальных групп, наций, государств) (Strauss 1998b: 254). Если первое доступно всем людям без исключения, то второе становится очевидным тем, кто изучает священные тексты.

Специальное откровение имеет высшую точку развития в Евангелии Иисуса Христа, Которого церковь называет Словом Божьим. Знать о Слове Божьем мы, в первую очередь, можем из слов записанных свидетельств, содержащихся в евангельских и апостольских текстах. Сам язык Библии, а не только общие идеи в отрыве от него, является предметом откровения, которое церковь доносит до людей. Социальная борьба женщин и иных дискриминируемых групп за свои права зачастую вытесняет в современной англиканской проповеди теологическую ортодоксию на периферию.

Тем не менее, гендерно-нейтральные стратегии политкорректной англиканской проповеди, зародившиеся в рамках феминистского дискурса в западных 
неолиберальных англоговорящих сообществах во второй половине XX в., представляют немалый интерес для филологов. Они позволяют выявить особенности современной христианской гомилетики как литературного жанра, проследить эволюцию этого жанра от классических посылок к неклассическим, а также проанализировать социальные и политические дискурсы, стоящие за христианской проповедью в современном мире.

(C) К.С. Шаров, 2019

\section{СПИСОК ЛИТЕРАТУРЫ / REFERENCES}

Бернатоните, А.К. Семантика образов членов семьи в их взаимоотношениях с гостем в тексте

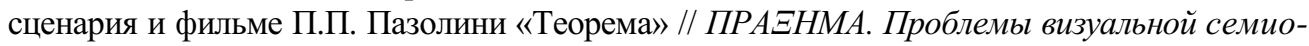
тики. 2017. № 2 (12). C. 125-145. [Bernatonite, Ada (2017). The Semantics of Family Members Images in Their Relationships with a Guest in the Script and P. P. Pasolini's Movie 'Theorem'. ПРА ЕHMA. Journal of Visual Semiotics, 4(2), 125-145. (In Russ.)]

Воронина О.А. Оппозиция материи и духа: гендерный аспект // Bопросы философии. 2007. № 2. C. 56-65. [Voronina, Olga (2007). Matter and Spirit Opposition: Gender Aspect. Voprosy filosofii, (2), 56-65. (In Russ.)]

Габриэлян, Н.М. Всплывающая Атлантида (медитация на тему феминизма) // Общественные науки и современность. 1993. № 6. C. 171-176. [Gabrielyan, Nina (1993). Vsplyvayushchaya Atlantida (meditatsii na temu feminizma) [Swimming-up Atlantis (meditations on feminism)]. Obshchestvennye Nauki i Sovremennost, (6), 171-176. (In Russ.)]

Гендер и язык. Антология. М.: Языки славянской культуры, 2005. [Gender and Language. Anthology (2005) Moscow: Yazyki slavyanskoy kultury. (In Russ.)]

Донских, О.А. Метафора как способ смены координат // ПРАЕНМА. Проблемы визуальной семиотики. 2015. № 1 (3). С. 29-35 [Donskikh, Oleg (2015). Metaphor as a way to change coordinates. ПРА $\Xi H M A$. Journal of Visual Semiotics, (1), 29-35 (In Russ.)]

Карасев, Л.В. Гоголь и онтологический вопрос // Вопросы философии. 1993. № 8. С. 84-96 [Karasev, Leonid (1993). Gogol and ontological question. Voprosy filosofii, (8), 84-96. (In Russ.)].

Карасев, Л.В. Об «Интересном» Я. Голосовкера // Вопросы философии. 2017. № 3. С. 114124 [Karasev, Leonid (2017). On J. Golosovker's “The Interesting”. Voprosy filosofii, (3), 114-124. (In Russ.)].

Карасев, Л.В. Nervoso Fasciculoso (о внутреннем содержании гоголевской прозы) // Bonpocbl философии. 1999. № 9. С. 43-65 [Karasev, Leonid (1999). Nervoso fasciculoso (About internal content of Gogol's prose). Voprosy filosofii, (9), 43-65. (In Russ.)].

Киселев, Г.С. Постмодерн и христианство // Вопросы философии. 2001. № 12. С. 3-15. [Kiselev, Grigory (2001). Postmodernity and Christianity. Voprosy filosofii, (12), 3-15. (In Russ.)]

Киселев, Г.С. Религиозные смыслы мира человека // Вопросы философии. 2011. № 5. С. 18-29. [Kiselev, Grigory (2011). Religious meanings of the human's world. Voprosy filosofii, (5), 18-29. (In Russ.)]

Кофанов, Л.Л. Римское право в Испании до введения Lex Wisigothorum // $Х Х О Н Н$. Философское антиковедение и классическая традиция. 2010. Т. 4. № 1. С. 64-77. [Kofanov, Leonid (2010). Roman law in Spain prior to the Lex Wisigothorum. XOAH. Ancient Philosophy and the Classical Tradition, 4(1), 64-77. (In Russ.)] 
Мольтманн-Вендель, Э. И сотворил Бог мужчину и женщину (Феминистская теология и человеческая идентичность) // Вопросы философии. 1991. № 3. С. 91-104. [Moltmann-Wendel, Elisabeth (1991). And God Created Man and Wife (Feminist Theology and Human Identity). Voprosy filosofii, (3), 91-104. (In Russ.)]

Назарчук, А.В. Сетевое общество и его философское осмысление // Вопросы философии. 2008. № 7. C. 61-75. [Nazarchuk, Alexander (2008). Network society and its philosophic contemplation. Voprosy filosofii, (7), 61-75. (In Russ.)]

Назарчук, А.В. Осмысление коммуникации в современной французской философии // Boпросы философии. 2009. № 8. C. 147-162. [Nazarchuk, Alexander (2009). Considering the communication in the modern French philosophy. Voprosy filosofii, (8), 147-162. (In Russ.)]

Пиков, Г.Г. О некоторых особенностях библейской криминологии // $Х Х О Н$. Философское антиковедение и классическая традииия. 2010. T. 4. № 1. С. 101-136. [Pikov, Gennady (2010). Criminal law in the Bible. XOAH. Ancient Philosophy and the Classical Tradition, 4 (1), 101-136. (In Russ.)]

Райкова, О.А. Пространство женской инициации и опыт сакрального (на материале первобытных обществ) // ПРА [Raykova, Olga (2016). the environment of women's initiation and experience of the sacred (on the material of primitive societies). ПРА $\Xi H M A$. Journal of Visual Semiotics, 3(4), 66-81. (In Russ.)]

Сазонова, Н.И. Действо о страшном суде в православном богослужении России в XVII в.: к проблеме типологических характеристик богослужебного действа // ПРА $Н М А$. Проблемы визуальной семиотики. 2016. № 4(10). С. 53-65. [Sazonova, Natalia (2016). Action about Day of Judgment in the Orthodox divine service in the seventeenth century: To the problem of typological characteristics of divine service action. ПРА $\Xi H M A, 3(4), 53-65$. (In Russ.)]

Санников, С.В. Развитие представлений о преступлениях против королевской власти в раннесредневековой германской правовой культуре: от частного правонарушения к государственной измене // ГХОАН. Философское антиковедение и классическая традиция. 2010. T. 4. № 1. C. 78-100. [Sannikov, Sergey (2010). Offences again royal power in Early Medieval German law: from civil delictum to treason. $\Sigma X O \Lambda H$. Ancient Philosophy and the Classical Tradition, 4 (1), 78-100. (In Russ.)]

Фёдоров, В.В., Фёдоров, М.В., Коротаева, З.В. Предикторы пространства власти: семантический аспект // ПРАЕНМА. Проблемы визуальной семиотики. 2015. Т. 2. № 3 (5). С. 8696. [Fedorov, Viktor; Fedorov Mikhail; Korotaeva Zinaida (2015). Predictors of power space: The semantic aspect. ПРАЕHMA. Journal of Visual Semiotics, 2 (3), 86-96. (In Russ.)]

Хитрук, Е.Б. Визуализация «отцовской революции» в контексте смены философских парадигм // ПРАЕНМА. Проблемы визуальной семиотики. 2016. Т. 3. № 2 (8). С. 97-107. [Khitruk, Ekaterina (2016). Visualising the 'father's revolution' in the context of philosophy paradigms change. ПРАЕHMA. Journal of Visual Semiotics, 3(2), 97-107. (In Russ.)]

Шаров, К.С. Гендерные аспекты семиотики моды // Вопросы философии. 2007. № 12. С. 50-64 [Sharov, Konstantin (2007). Gender aspects of fashion semiotics. Voprosy filosofii, (12), 50 64. (In Russ.)].

Шаров, К.С. Гоголь в тексте // Вопросы философии. 2013. № 8. С. 131-136 [Sharov, Konstantin (2013). Gogol in the text. Voprosy filosofii, (8), 131-136. (In Russ.)].

Шаров, К.С. Древний Рим и женщины-администраторы // इХОАН. Философское антиковедение и классическая традиция. 2019. Т. 13. № 1. С. 106-114. [Sharov, Konstantin (2019). Ancient Rome and Female Administrators. $\mathrm{XO \Lambda H.} \mathrm{Ancient} \mathrm{Philosophy} \mathrm{and} \mathrm{the} \mathrm{Classical} \mathrm{Tradition,}$ 13 (1), 106-114. (In Russ.)] 
Шаров, К.С. Д.Н. Кавтарадзе - Мастерская игр. Ремесло и искусство // Вопросы философии. 2015. № 7. C. $210-215$ [Sharov, Konstantin (2015). D. N. Kavtaradze - Game workshop. Craft and art. Voprosy filosofii, (7), 210-215. (In Russ.)]

Шаров, К.С. Мужчины и женщины в вербальной коммуникации: проблема гендерлекта // Вопросы философии. 2012. № 7. С. 38-51. [Sharov, Konstantin (2012). Men and women in the verbal communication: The problem of genderlect. Voprosy filosofii, (7), 38-51. (In Russ.)]

Шаров, К.С. На темной стороне политкорректности: гендерно-нейтральный новояз // Bonpoсbl философии. 2010. № 3. С. 30-43. [Sharov, Konstantin (2010). At the dark side of political correctness: gender-neutral new language. Voprosy filosofii, (3), 30-43. (In Russ.)]

Шаров, К.С. Симуляция-игра отличительных национальных признаков в музыке // Bonpocbl философии. 2006. № 7. С. 45-56 [Sharov, Konstantin (2006). The 'simulation - game' of distinct national features in music. Voprosy filosofii, (7), 45-56. (In Russ.)].

Шевцов, С.П. Римское право в свете истории ментальности // БХОАН. Философское антиковедение и классическая традиция. 2010. Т. 4. № 1. С. 9-31. [Shevtsov, S. P. (2010). Roman Law in the light of the history of mentality. $\Sigma X O \Lambda H$. Ancient Philosophy and the Classical Tradition, 4(1), 9-31. (In Russ.)]

Afonasin, Eugene (2014). The pilot metaphor and its artistic reflections (a note on the platonic motive on some Celtic coins). ПРА $\Xi H M A$. Journal of Visual Semiotics, (1), 23-30.

Andina, Tiziana. (2015). Embodied meanings and normativity. Some remarks for a new concept of art. ПРА ЕНMA. Journal of Visual Semiotics, (4), 11-27.

Archibald-Barber, Jesse (n.d.) From Grammatical to Natural Gender. Retrieved from http://homes.chass.utoronto.ca/ cpercy/courses/6361 ArchibaldBarber.htm.

Baranov, Vladimir (2018). Classical Philosophy in the Homily on the Transfiguration of the Lord by Andrew of Crete. $\Sigma X O 1 H$. Ancient Philosophy and the Classical Tradition, 12(2), 433- 443

Barr, Beth Allison (2014). "he is bothyn modyr, broyp yr, \& syster vn-to me": Women and the Bible in Late Medieval and Early Modern English Sermons. Church History and Religious Culture, 94 (3), 297-315.

Calvo, Jose Maria Zamora (2018). The Christ-Logos question in Amelius. ¿XOAH. Ancient Philosophy and the Classical Tradition, 12 (2), 365-379.

Carson, Donald Arthur (1998). The Inclusive Language Debate. Grand Rapids, MI: Baker.

Castelli, Elizabeth (1990). Les Belles Infidèles/Fidelity or Feminism? The Meanings of Feminist Biblical Translation. Journal of Feminist Studies in Religion, 6 (2), 25-39.

Collins, Ken, rev. (n.d.) The Problem with Inclusive-Language Bible Translations. Ken Collins Website. Retrieved from http://www.kencollins.com/bible/bible-t6.htm.

Curzan, Anne (2003). Gender Shift in the History of English. Cambridge: Cambridge University Press.

Dallas, Joe (2007). The Gay Gospel?: How Pro-Gay Advocates Misread the Bible. Eugene, OR: Harvest House Publ.

Deeb-Sossa, Natalia; Kane, Heather (2007). "It's the Word of God": Students' Resistance to Questioning and Overcoming Heterosexism. Feminist Teacher, 17 (2), 151-169.

De Waard, Jan; Nida, Eugene (1986). From One Language to Another: Functional Equivalence in Bible Translation. Nashville, TN: Thomas Nelson Inc.

Donskikh, Oleg (2018) Splitting concepts: steps of reflection. इXO1H. Ancient Philosophy and the Classical Tradition, 12 (2), 402-425.

Fletcher, Michelle (2014) What Comes into a Woman and What Comes Out of a Woman: Feminist Textual Intervention and Mark 7:14-23. Journal of Feminist Studies in Religion, 30 (1), $25-41$. 
Fuchs, Esther (2008). Reclaiming the Hebrew Bible for Women: The Neoliberal Turn in Contemporary Feminist Scholarship. Journal of Feminist Studies in Religion, 24 (2), 45-65.

Gomola, Alexander (2010). Feminist thought in Bible translations. Przektadaniec. A Journal of Literary Translations, 24(), 193-208.

Gross, Martine (2008). To Be Christian and Homosexual: From Shame to Identity-Based Claims. Nova Religio: The Journal of Alternative and Emergent Religions, 11 (4), 77-101. DOI: 10.1525/nr.2008.11.4.77.

Grudem, Wayne (1998). A Response to Mark Strauss' Evaluation of the Colorado Springs Translation Guidelines. The Journal of the Evangelical Theological Society, 41(June), 263-286.

Grudem, Wayne; Osborne, Grant (1997). Do Inclusive-Language Bibles Distort Scripture? Christianity Today, (October), 26-39.

Jacobs, Maretha (2001). Feminist scholarship, biblical scholarship and the Bible. Neotestamentica, $35(1 / 2), 81-94$.

Jones, Charles (1988). Grammatical Gender in English: 950 to 1250. London: Croom Helm.

Joussellin, Charles, Mailenova, Farida (2018). L'objectivation du corps et nouvelles technologies. ПРА ЕНMA. Journal of Visual Semiotics, (4), 142-147.

Kettemann, Bernhard; Marko, Georg (2005). "But what does the Bible really say?" A Critical Analysis of Fundamentalist Discourse. AAA: Arbeiten aus Anglistik und Amerikanistik, $30(1 / 2), 201-225$.

Lathrop, Gordon; Ramshaw, Gail (1993). Psalter for the Christian People: An Inclusive Language ReVision of the Psalter of the Book of Common Prayer 1979. Tucson, AZ: Pueblo Books.

Martin, Carol (1990). Womanist Interpretations of the New Testament: The Quest for Holistic and Inclusive Translation and Interpretation. Journal of Feminist Studies in Religion, 6 (2), 41-61.

Meyers, C.L. (2014). Was Ancient Israel a Patriarchal Society? Journal of Biblical Literature, 133 (1), $8-27$.

Minton, Ron. (2003). Gender-Inclusive Bible Translations. Chafer Theological Seminary Journal, 9 (Spring), 141-146. Retrieved from https://deanbible.org/dbmfiles/slides/x2012-ChaferNTTextualCriticism-8-GenderInclusiveBibleMinton.pdf.

Moltmann-Wendel, Elisabeth. (1991). And God Created Man and Wife (Feminist Theology and Human Identity). Voprosy filosofii, (3), 91-104. (In Russ.)

Poythress, Vern; Grudem, Wayne. (2000). The Gender-Neutral Bible Controversy. Nashville, TN: Broadman and Holman.

Protopopova, Irina; Garadja, Alexei (2018). Reading a woman (Rep. 454d). $\Sigma X O 1 H$. Ancient Philosophy and the Classical Tradition, 12 (2), 426-432.

Ringer, Wesley (n.d.) What are the Biblical Translation Issues Raised by the Gender-Inclusive Debate? Retrieved from http://www.godandscience.org/doctrine/gender.html.

Robbins, Mandy (2001). Clergywomen in the Church of England and the Gender Inclusive Language Debate. Review of Religious Research, 42 (4), 405-414.

Sassin, Wolfgang; Donskikh, Oleg, Gnes, Alexandre; Komissarov, Sergei; Liu Depei (2018). Evolutionary Environments. Homo Sapiens — an Endangered Species? Innsbruck: Studia Universitätsverlag, 2018.

Schüssler-Fiorenza, Elisabeth. (1992). But She Said: Feminist Practices of Biblical Interpretation. Boston: Beacon Press.

Schüssler-Fiorenza, Elisabeth (1995). Bread not Stone: The Challenge of Feminist Biblical Interpretation. Boston: Beacon Press. 
Shakespeare, Steven (2009). Prayers for an Inclusive Church. Boston: Church Publ.

Shevtsov, Sergey (2010). Roman Law in the light of the history of mentality. $\Sigma X O \Lambda H$. Ancient Philosophy and the Classical Tradition, 4(1), 9-31. (In Russ.)

Stein, David (2008). On Beyond Gender: Representation of God in the Torah and in Three Recent Renditions into English. Nashim: A Journal of Jewish Women's Studies and Gender Issues, (15), $108-137$.

Stein, John. (1995). America's Bibles: Canon, Commentary, and Community. Church History, 64 (2), $169-184$.

Strauss, Mark (1998a). Distorting Scripture? Gender-Inclusive Language and the Bible. Downers Grove, IL: InterVarsity.

Strauss, Mark (1998b). Linguistic and Hermeneutical Fallacies in the Guidelines Established at the 'Conference on Gender-Related Language in Scripture'. The Journal of the Evangelical Theological Society, 41(June), 239-262.

Tantlevskij, Igor (2016). Further Considerations on Possible Aramaic Etymologies of the Designation

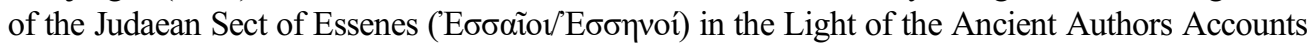
of Them and the Qumran Community World-View. $\mathrm{XO \Lambda H}$. Ancient Philosophy and the Classical Tradition, 10 (1), 61-75.

Tantlevskij, Igor (2017). Possible parallels in Ecclesiastes' and Aristotle's reflections concerning the eternity and immortality of the soul in correlation with its intellectual and ethical merits. ¿XO1H. Ancient Philosophy and the Classical Tradition, 11 (1), 133-143.

Tantlevskij, Igor (2019). Allegories of life, death and immortality in the book of Ecclesiastes. ¿XO1H. Ancient Philosophy and the Classical Tradition, 13 (1), 48-57.

Terezis, Christos; Petridou, Lydia (2017) The theory of 'union - distinction' as a paradigm of Gr. Palamas' methodology. $\mathrm{XO \Lambda H.} \mathrm{Ancient} \mathrm{Philosophy} \mathrm{and} \mathrm{the} \mathrm{Classical} \mathrm{Tradition,} 11$ (1), $117-132$.

Ward, Graham (1994). In the name of the father and of the mother. Literature and Theology, 8 (3), $311-327$.

Welch, Martin (1992). Anglo-Saxon England. London: English Heritage.

Whitehead, Andrew; Perry, Samuel (2015). A More Perfect Union? Christian Nationalism and Support for Same-sex Unions. Sociological Perspectives, 58 (3), $422-440$.

Whorf, Benjamin Lee (1945). Grammatical Categories. Language, 21 (1), 1-11.

\section{Словари и электронные ресурсы / Dictionaries and links}

Библейские переводы. Энциклопедический словарь Брокгауза и Ефрона в 86 т. СПб.: Изд-во Его Императорского Величества, 1890-1907. [Biblical Translations (1890-1907) Encyclopaedic Dictionary of Brokhauz and Efron (in 86 vols). St Petersburg: His Imperial Majesty's Press. (In Russ.)]

Bible Gateway (n.d.) Retrieved from https://www.biblegateway.com/versions.

Biblical Revelation and Inclusive Language. A Report of the Commission on Theology and Church Relations of the Lutheran Church - Missouri Synod. (1998). Retrieved from https://www.lcms.org/Document.fdoc?src=lcm\&id=314.

Biblical Translations (1890-1907) Encyclopaedic Dictionary of Brokhauz and Efron (in 86 vols). St Petersburg: His Imperial Majesty's Press. (In Russ.)

The Inclusive Bible: The First Egalitarian Translation (by Priests for Equality) (2009). New York: Sheed \& Ward. 
The New Testament and Psalms (inclusive version) (1995). Oxford: Oxford University Press. The Queen James Bible (2012). New York: Queen James Press.

What does the Bible say about political correctness? (n.d.) Got Questions. Retrieved from https://www.gotquestions.org/political-correctness.html

\section{Сведения об авторе:}

КОНСТАНТИН СЕРГЕЕВИЧ ШАРОВ — кандидат философских наук; старший преподаватель философского факультета Московского государственного университета имени М.В. Ломоносова. Сфера научных интересов: компаративистика, сравнительно-историческое языкознание, сравнительное литературоведение.

Контактная информация: e-mail: const.sharov@mail.ru

\section{Bionote:}

KONSTANTIN SHAROV - Ph.D., Senior Lecturer at M.V. Lomonosov Moscow State University. Research interests: comparative and historical studies of language and literature.

Contact information: e-mail: const.sharov@mail.ru

\section{Article history:}

Received: 02 December 2018

Revised: 26 February 2019

Accepted: 10 March 2019

\section{История статьи:}

Дата поступления в редакцию: 02 декабря 2018

Дата принятия к печати: 10 марта 2019 